\title{
高分子電解質の水溶液物性
}

高分子電解質の水溶液基礎物性は非電解質高分子に比べてはるかに 複雑で未解決な問題を多く含んでいる。高分子電解質の希薄溶液物性 の中でも中心的課題である, 対イオン凝縮, 静電的持続長と排除体積 効果, 無塩系での還元粘度の異常性について, 近年の進歩と筆者らの 理解を解説しながら展望した。

\section{川口正 剛}

\section{1. はじめに}

高分子電解質はその鎖上に多数の解離基を有する高分子 の総称で, 高分子亡電解質の両方の性質を併せ持つが両者 の相乗効果によって中性高分子や低分子電解質の溶液では 見られない特異な溶液の性質を示す。おおむね高分子電解 質は水溶性で水中では高分子イオンとその周囲のイオン雾 井気を形成する対イオンとに解離する。高分子イオンは解 離基が多数密集しているため, その解離によって強い静電 場を生じ, この静電気力により周辺に対イオンが凝集する 結果, 対イオン活量の顕著な低下を引き起こす。また, 高 分子イオン一本鎖の形態はおもに静電的な相互作用によっ て支配されるので，塩濃度の減少に伴い顕著に膨張する。

高分子電解質の溶液物性に関する研究は他の非電解質高 分子と同程度に古く，1950～1960 年代にはすでに日本を 含む数グループによって先駆的な業績が生み出された1，2)。 その後, 日本 ${ }^{3}$ および欧米の研究者らによる理論構築およ び実験的検証に関して膨大かつ精力的な基礎研究が積み重 ねられ, 現在の理解に至っている。しかしながら, 高分子 電解質の希薄溶液論は非電解質高分子のそれと比心゙て実験 的にも理論的にもはるかに難しく, 標準理論はいまだに確 立されていないの屯実状であろう

本稿では, 高分子電解質の希薄溶液物性の中であとくに 中心的な課題である, “対イオン凝縮”, 孤立高分子鎖の形 態に関する “静電的持続長と排除体積効果”, 高分子電解質

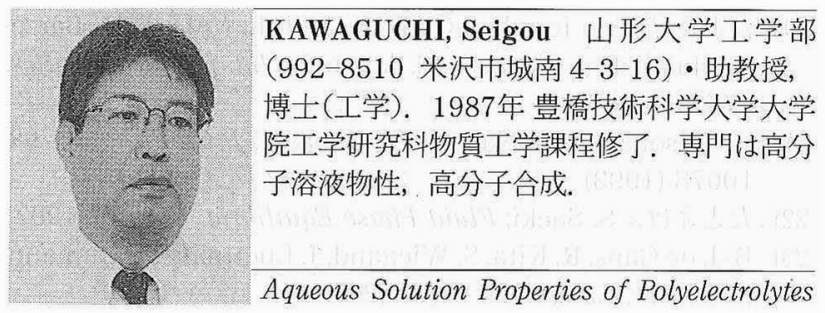

の性質があっとも顕著に現れる“無塩系における還元粘度 の異常性”について, 近年の進歩と筆者らの理解を解説し ながら展望する。

\section{2. 対イオン凝縮}

高分子電解質研究の初期の段階から, 対イオンの相当量 が高分子イオンに束縛された状態にあり, 対イオン活量や 浸透圧が著しく低下することなどが認められた。とくに棒 状分子では解離基間距離が 7 Å以下になると, 活量係数は 0.2 0.4 程度まで減少し, 残りの対イオンは高分子鎖近傍 に強く束縛されていること，これは高分子濃度にあまりよ らないこと一“対イオン凝縮”一が実験的に確かめられ た7て 14)。この現象は棒状分子 1 個あたりに割り振った円筒 形の自由空間を想定し, Poisson-Boltzmann (P-B) 方程式 の解を用いてなされた ${ }^{15)}$ 。すなわち，高分子鎖は局所的に 見ればその静電反発力により棒状と見なされることから， 棒亡して解離基をその中心軸上へ射影したとき（図 1)，平 均解離基間間隔を $b$, 高分子の解離基および対イオンの価 数を 1 上すると, 電荷密度パラメーター

$$
\xi=e^{2} / 4 \pi D k T b
$$

が 1 以上のときに対イオン凝縮を起こすことが導かれた。 ここで, $e$ は電気素量, $D$ は誘電率， $k$ はボルッマン定数, $T$ は絶対温度である。またこの関係はより単純な高分子相 と溶媒相との間のイオン分布を 2 相モデルとして取扱っ て得られた（大沢-Manning）理論 ${ }^{2)}{ }^{16)}$ によと， $\xi<1 の$ 場合, 対イオンは自由空間内で高分子イオンと緩やかな相 互作用すると仮定すると対イオン活量係数 $(\gamma)=\xi^{-1} e^{-0.5}$ となる。一方 $\xi>1$ の場合, $1-1 / \xi$ 割合の対イオンは高分 子鎖近傍に強く束縛され, 残りは高分子イオンと緩やかな 相互作用をすると考え， $\gamma=e^{-0.5 \xi}$ で表される。この理論は イオン吸着の単純な描像を与え, その後多くの実験結果と 


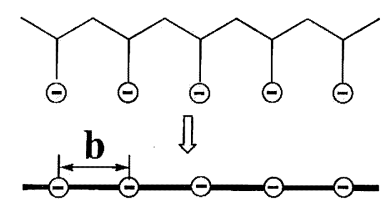

図 1 高分子電解質鎖のひとつのモデル

対比されることになったが，おおむ㸚実験結果を半定量的 に説明できた点で功績は大きい。近年，カチオン性のアイ オネン高分子電解質と添加塩との相加性の問題に関して, 相加性からの大きなずれす報告されており，塩添加による 高分子鎖の柔軟性の増加之関連して論じられている17)。

高分子弱酸などの $\mathrm{pH}$ 滴定は一般に次式で定義される見 かけの解離定数 $\mathrm{p} K_{\mathrm{a}}$ で記述される。

$$
\mathrm{p} K_{\mathrm{a}} \equiv \mathrm{pH}-\log \frac{\alpha}{1-\alpha}=\mathrm{p} K_{0}+0.4343 \frac{\partial G_{\mathrm{el}} / \partial \alpha}{R T}
$$

ここで, $\alpha$ は解離度, $\mathrm{p} K_{0}$ は固有の解離定数， $G_{\mathrm{el}}$ は静電的 なギブス自由エネルギーでプロトン $1 \mathrm{~mol}$ が高分子イオ ンからの静電引力に逆らって解離するときの静電的仕事に 関係する。それは，高分子鎖を表面に電荷を一様にならし た無限帯電棒と仮定し, P-B 方程式からの静電ポテンシャ

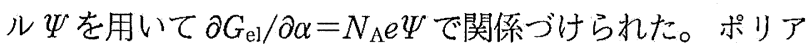
クリル酸18)などさまざまな高分子弱酸の電位差滴定は上述 のモデルで比較的よく記述できたが，一方では不一致む数 多く報告された。離散電荷モデルに基づいた Ising モデル

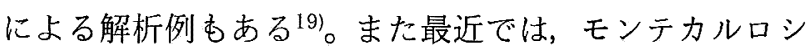
ミュレーション法を利用して，円筒セル内のイオン分布を 求めて P-B 方程式などと比較するとともに，浸透圧やイオ ン活量などの熱力学量を算出して実験結果と比較すること あ試みられている20)。

\section{3. 静電的持続長と排除体積効果}

高分子電解質鎖の 2 乗回転半径 $\left\langle S^{2}\right\rangle$ は塩濃度に非常に 敏感で, 良溶媒中の非電解質高分子のそれに比べてはるか に拡がる。高分子電解質の電荷間に働く力は扔もに静電力 であるため，高分子電解質鎖は分子量のみならず，電荷密 度, 塩濃度の変化とともに劇的に変化する ${ }^{21)}$ (図 2)。一般 に柔軟な非電解質高分子鎖の拡がりは, 高分子鎖に沿って 比較的近くの置換基間に働く近距離相互作用之遠距離相互 作用（排除体積効果）によって決定される。

最近の研究によると非電解質高分子に対するみみず鎖沶 よびらせんみみず鎖に基づいた準 2 定数理論 (QTP) は高 分子鎖の剛さによらず, $\left\langle S^{2}\right\rangle$ や $[\eta]$ に及ぼす排除体積効果 をほぼ定量的に記述できる。したがって，高分子電解質鎖 の形態についてあ非電解質高分子之同様に持続長と排除体 積の寄与を分離して取扱うことが肝要である22)。

Kratky-Porod みみず鎖モデル23)では，非摂動状態にお ける $\left\langle S^{2}\right\rangle$ は，分子鎖長 (contour length) $L$ 之持続長 (per-

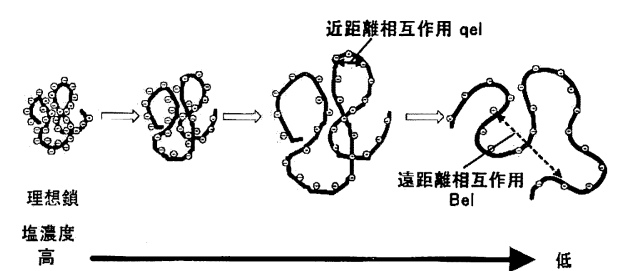

図 2 塩濃度の変化に伴う高分子電解質鎖の拡がりに関する 模式図

sistence length) $q$ を用いて

$$
\left\langle S^{2}\right\rangle_{0}=\frac{q L}{3}-q^{2}+\frac{2 q^{2}}{L}-\frac{2 q^{4}}{L^{2}}[1-\exp (-L / q)]
$$

で表される。良溶媒中，山川-Stockmayer-島田 (YSS) 理 論 ${ }^{24)}$ による準 2 定数理論によると，分子内排除体積効果に よる鎖が大きくなる度合い $\alpha_{\mathrm{s}}{ }^{2}=\left(\left\langle S^{2}\right\rangle /\left\langle S^{2}\right\rangle_{0}\right)$ は次式で与 えられる修正排除体積パラメーター $゙$ のみ関数となる。

$$
\tilde{z}=(3 / 4) K(\lambda L)(3 / 2 \pi)^{3 / 2}(\lambda B)(\lambda L)^{1 / 2}
$$

ここで $\lambda^{-1}=2 q, B$ は排除体積強度, 2 体クラスター積分 $\beta$ とビーズ間距離 $a$ と $B=\beta / a^{2}$ の関係がある。また, $K(\lambda L)$ は以下の式で与えられる。

$$
\begin{aligned}
K(\lambda L)= & 4 / 3-2.711(\lambda L)^{-1 / 2}+7 / 6(\lambda L)^{-1} \\
& \text { for } \lambda L>6 \\
K(\lambda L)= & (\lambda L)^{-1 / 2} \exp \left(-6.611(\lambda L)^{-1}+0.9198\right. \\
& +0.03516 \lambda L) \quad \text { for } \lambda L \leq 6
\end{aligned}
$$

$\alpha_{\mathrm{s}}{ }^{2}$ や極限粘度に対する $\alpha_{\eta}{ }^{3}=[\eta] /[\eta]_{0}$ については, 次式で 与えられる Domb-Barret 関数 ${ }^{25)}$ を用い実験值と理論值之 を比較することによって持続長 $q$ と排除体積強度 $B$ を分 離して評価することができる。

$$
\begin{aligned}
\alpha_{\mathrm{s}}{ }^{2}= & {\left[1+10 \tilde{z}+\left(\frac{70 \pi}{9}+\frac{10}{3}\right) \tilde{z}^{2}+8 \pi^{3 / 2} \tilde{z}^{3}\right]^{2 / 15} } \\
& \times\left[0.933+0.067 \exp \left(-0.85 \tilde{z}-1.39 \tilde{z}^{2}\right)\right] \\
\alpha_{\eta}{ }^{3}= & {[\eta] /[\eta]_{0}=\left(1+3.8 \tilde{z}+1.9 \tilde{z}^{2}\right)^{0.3} }
\end{aligned}
$$

高分子電解質の場合， $q$ は一般に次式で与えられる。

$$
q=q_{0}+q_{\mathrm{el}}
$$

ここで, $q_{\mathrm{o}}$ は高分子鎖固有の持続長, $q_{\mathrm{el}}$ は静電的持続長で Odijk-Skolnick-Fixman (OSF) 理論26)では次式で与えら れる。

$$
q_{\mathrm{el}}=\frac{1}{4 \kappa^{2} Q_{\mathrm{B}}} \lambda_{\mathrm{eff}^{2}}
$$

ここで, $\kappa^{-1}$ はDebye-Hückelの遮蔽長で1-1塩系では $\kappa^{2}=$ $8 \pi Q_{\mathrm{B}} N_{\mathrm{A}} C s / 1000, Q_{\mathrm{B}}$ は Bjerrum 長で, $Q_{\mathrm{B}}=e^{2} / 4 \pi D k T=$ $0.714 \mathrm{~nm}, \lambda_{\text {eff }}$ は有効電荷密度で $\lambda_{\text {eff }}=Q_{\mathrm{B}} / b$ である。一 方, 全排除体積強度 $B$ は, 八ードコア斥力項 $B_{\mathrm{c}}$ と引力項 $B_{\mathrm{a}}$ および静電項 $B_{\mathrm{el}}$ の和として次式で与えられる ${ }^{27)}$ 。

$$
B=B_{\mathrm{c}}+B_{\mathrm{a}}+B_{\mathrm{el}}
$$

Fixman-Skolnik (FS) 理論 ${ }^{28)}$ によと， $B_{\mathrm{el}}$ はビーズ直径 $d_{\mathrm{c}}$ と $y=2 \pi b^{-2} Q_{\mathrm{B}} \kappa^{-1} \exp \left(-\kappa d_{\mathrm{c}}\right)$ を用いて

$$
B_{\mathrm{el}}=(2 / \kappa)(\pi / 4)(\ln y+0.7704)
$$




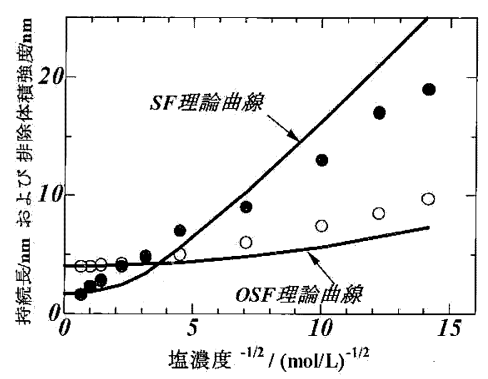

図 3 ヒアルロン酸ナトリウムの持続長 $q(\bigcirc)$ 之排除体積強 度 $B(\bullet)$ の塩濃度依存性 ${ }^{28)}$

実線は $q_{0}=4 \mathrm{~nm}, B_{0}=1.6 \mathrm{~nm}, b=1 \mathrm{~nm}, d_{\mathrm{c}}=1.0 \mathrm{~nm}$ を用いて計算した理論曲線

比較的柔軟な高分子鎖 $\left(q_{0}=4 \mathrm{~nm}\right)$ であるヒアルロン酸 ナトリウムに対して $0.005 \mathrm{M}<C s<2.5 \mathrm{M} \mathrm{NaCl}$ 濃度で決 定した $q$ とBの実験值 ${ }^{28)} と(9) \sim(12)$ 式加ら計算される理 論曲線の比較を図 3 に示した。塩濃度の減少に伴い持続長 および排除体積強度の両方が増加しているが，後者は前者 より顕著に増加している。一見，OSF 理論扔よび FS 理論 は実験デー夕を半定量的に記述しているように見えるが， さらに柔軟な高分子鎖からなるビニル高分子電解質である ポリスチレンスルホン酸ナトリウム鎖 $\left(q_{0}=0.69 \mathrm{~nm}\right)$ につ いては理論との一致は必ずしも十分ではない29)。高分子電 解質鎖の 1 次構造の違いによる個性も考慮する必要があ ろう。今後, 塩濃度がさらに低い領域での実験と柔軟な高 分子電解質鎖まで記述できる理論の構築が望まれる。

\section{4. 無塩系における粘度}

無塩系における高分子電解質水溶液の挙動はさらに複雑 である。無塩系高分子イオン水溶液ではきわめて遠距離間 の規則性の存在が示唆されている ${ }^{30)}, 31 \%$ 。また, 無塩系高分 子電解質水溶液を希釈すると還元粘度が急激に増大するこ とが古くから知られている。その解釈として従来, 希勫に伴 い静電反発で高分子鎖が伸びるためであると信じられてき た。しかし最近，西田ら ${ }^{32)}$ は還元粘度の濃度変化の詳細な 検討を行い, 分子内, 分子間の相互作用を分離することを 試み, 粘度の極大值に関しては高分子イオン間の相互作用 によるあのであること, 中山ら ${ }^{33)}$ は無塩系において高分子 鎖は決して伸びきり鎖とはならないことなどを報告した。

以上，高分子電解質希薄水溶液の基礎物性に関して現在 の理解について記した。高分子電解質は従来のスケール防 止剤または凝集剤への工業的利用に加えて，近年では燃料 電池のイオン交換膜や高分子イオンコンプレックスとして 各種先端材料に利用されている。また, 高分子合成の進歩 に伴って各種の両親媒性高分子電解質の合成や自己組織化 構造に関する研究も多数報告されている ${ }^{34), 35)}$ 。高分子電解 質水溶液の基礎物性の本質を知ることは, 生体高分子や高 分子ゲルの機能発現との関連も含めて今後ますます重要に なってくるものと考えられる。

\section{文献}

1) S. A. Rice, M. Nagasawa: "Polyelectrolyte Slutions," Academic Press, 1962

2) F. Oosawa: "Polyelectrolytes," Marcel Dekker, 1971

3) M. Nagasawa Ed.: "Molecular Conformation and Dynamics of Macromolecules in Condensed Systems," Elsevier, p. 49, 1988

4) (a) 西尾 卓, 南方 陽：高分子, 51, 492 (2002); (b) 古沢 浩：高分子, 53, $273(2004)$

5) J.-L. Barrat, J.-F. Joanny: Adv. Chem. Phys., 94, 1 (1997)

6) K. S. Schmitz, Ed.: "Macro-ion Characterization from Dilute Solutions to Complex Fluids," ACS Sym. Ser. 548, 1993

7) M. Nagasawa, I. Kagawa: J. Polym. Sci., 25, 61 (1957)

8) J. R. Huizenga, P. F. Grieger, F. T. Wall: J. Am. Chem Soc., $72,4228(1950)$

9) (a) M. Nagasawa, A. Takahashi, H. Izumi, I. Kagawa: $J$. Polym. Sci., 38, 213 (1959);

(b) Z. Alexandrowicz: J. Polym. Sci., 60, 91 (1959)

10) H. Eisenberg: J. Polym. Sci., 30, 47 (1958)

11) P. Ander, M. Kardan: Macromolecules, 17, 2431 (1984)

12) J. J. V. D. Klink, L. H. Zuiderwerg, J. C. Leyte: J. Chem. Phys., 60, 2391 (1974)

13) S. Koda, H. Nomura, M. Nagasawa: Biophys. Chem., 23, 147 (1985)

14) A. Minakata, N. Imai: Biopolymers, 11, 329 (1972)

15) S. Lifson, A. Katchalsky: J. Polym. Sci., 13, 43 (1954)

16) (a) G. S. Manning: J. Chem. Phys. 51, 924, 934 (1969); (b) G. S. Manning: Ann. Rev. Phys. Chem., 23, 117 (1972)

17) J. Nagaya, A. Minakata, A. Tanioka: Langmuir, 15, 4129 (1999)

18) M. Nagasawa, T. Murase, K. Kondo: J. Phys. Chem., 69, 4005 (1965)

19). S. Sasaki, A. Minakata: Biophys. Chem., 11, 199 (1980)

20) T. Nishio: Biophys. Chem., 71, 173 (1998)

21) I Noda, T. Tsuge, M. Nagasawa: J. Phys. Chem., 74, 710 (1970)

22) R. M. Davis: Macromolecules, 24, 1149 (1991)

23) O. Kratky, G. Porod: Recl. Trav. Chim. Pays-Bas, 68, 1106 (1949)

24) (a) H. Yamakawa, W. H. Stockmayer: J. Chem. Phys., 57, 2843 (1972);

(b) H. Yamakawa, J. Shimada: J. Chem. Phys., 85, 2607 (1985)

25) C. Domb, A. Barrett: Polymer, 17, 179 (1976)

26) (a) T. Odijk: J. Polym. Sci., Polym. Phys. Ed., 15, 477 (1977); (b) J. Skolnick, M. Fixman: Macromolecules, 10, 944 (1977)

27) M. Fixman, J. Skolnick: Macromolecules, 11, 863 (1978)

28) (a) K. Hayashi, K. Tsutsumi, T. Norisuye, A. Teramoto: Polym. J., 28, 922 (1996);

(b) K. Tsutsumi, T. Norisuye: Polym. J., 30, 345 (1998)

29) (a) E. Hirose, Y. Iwamoto, T. Norisuye: Macromolecules, $\mathbf{3 2}$ 8629 (1999);

(b) Y. Iwamoto, E. Hirose, T. Norisuye: Polym. J., 32, 428 (2000)

30) N. Ise: Angew. Chem., 25, 323 (1986)

31) T. Okubo: J. Chem. Soc., Faraday Trans., 82, 3175 (1986)

32) K. Nishida, K. Kaji, T. Kanaya: Polymer, 42, 8657 (2001)

33) J. Yamanaka, H. Matsuoka, H. Kitano, N. Ise: J. Am. Chem. Soc., 112, 587 (1990)

34) T. Noda, A. Hashidzume, Y. Morishima: Langmuir, 16, $5324(2000)$

35) たとえば B. S. Sumerlin, A. B. Lowe, D. B. Thomas, C. L. McCormick: Macromolecules, 36, 5982 (2003) 